\title{
Strategi Pengembangan Pembelajaran Pondok Pesantren Al Falah Somolangu Kebumen
}

\author{
Aly Ngusman \\ Pascasarjana IAINU Kebumen
}

Naskah diterima 28 April 2018, direvisi 20 Mei 2018, disetujui 13 Juli 2018

\begin{abstract}
Discussion about the role of boarding schools in the formation and development of education, in particular the Islamic education, in Indonesia hardly needs to be debated and doubt. Long before Indonesia became independent, the institutions lead by the scholars (kyai) is present in the Earth. History shows that the boarding school is not only able to keep resistance from exposure to the times, but also can take care of its development which continues to increase over time. According to existing data, the institution was first established, especially in Java, in the 15th century by Maulana Malik Ibrahim (one of the oldest walisongo) and then developed by the other walisongo. At the end of the 19th century, the number of boarding school in Java developed reaches 300 boarding school, and based on the Notes Database boarding schools of ministry of religion RI, the number of boarding schools the year 2018, this amounts to about 21,321. The resistance and sustainable development of the boarding schools that certainly could not be released from the academic tradition developed which has a pretty strong distinction. One of them is the pattern of his education is transformative. It makes boarding school is not simply a religious institution that merely engaged in the world of religious education for the students, but at the same time have the concern and active role of the community in jointly empower themselves. These values also did not escape from AlFalah boarding school Somolangu, Kebumen. It will also make boarding school can be instrumental in giving a concrete contribution for global life.
\end{abstract}

Keywords: Management, Education, Islamic Boarding Schools

Abstrak Berdiskusi tentang peran pondok pesantren dalam pembentukan dan pengembangan pendidikan, khususnya pendidikan Islam, di Indonesia nyaris tidak perlu diperdebatkan dan diragukan lagi. Jauh sebelum Indonesia merdeka, institusi 
yang dibidangi oleh para ulama (kyai) ini hadir di bumi Nusantara. Sejarah yang dilalui memperlihatkan bahwa pesantren bukan sekadar mampu menjaga kebertahanan dari terpaan zaman, tapi juga dapat merawat perkembangannya yang terus meningkat dari waktu ke waktu. Menurut data yang ada, lembaga ini pertama kali didirikan, khususnya di tanah jawa, pada abad ke-15 oleh Maulana Malik Ibrahim (salah satu walisongo tertua) dan kemudian ditumbuh-kembangkan oleh para wali songo yang lain. Pada akhir abad ke-19, jumlah pesantren di Jawa berkembang mencapai 300 buah, dan berdasarkan catatan Pangkalan Data Pondok Pesantren Kemenag RI, jumlah Pondok Pesantren tahun 2018 ini, berjumlah sekitar 21.321. Kebertahanan dan perkembangan berkelanjutan dari pondok pesantren itu tentu tidak bisa dilepaskan dari tradisi keilmuan yang dikembangkan yang memiliki distingsi cukup kuat. Salah satu di antaranya adalah pola pendidikannya yang bersifat transformatif. Hal ini menjadikan pesantren bukan sekadar institusi keagamaan yang sekadar berkiprah dalam dunia pendidikan keagamaan bagi para santri, tapi sekaligus memiliki kepedulian dan peran aktif bersama-sama masyarakat dalam memberdayakan diri mereka. Nilai-nilai tersebut juga tidak luput dari Pondok Pesantren AlFalah Somolangu, Kebumen. Hal itu juga akan menjadikan pesantren dapat berperan lebih besar dalam memberikan sumbangsih konkret bagi kehidupan global.

Kata kunci: Manajemen, Pondok Pesantren, Pendidikan Islam

\section{A. PENDAHULUAN}

Pondok pesantren merupakan agen pembangunan pendidikan agama dalam berbagai sektor kehidupan. Khususnya masalah pendidikan rohaniah. Tetapi kebanyakan pembinaan pendidikan keagamaan kurang memperhatikan aspirasi kebutuhan masyarakat sehingga kurang menyentuh nurani masyarakat umum. Salah satu yang menentukan bahwa pesantren tersebut memiliki kualitas yang baik terlihat dari manajemen pembelajaran santri yang diterapkan di pesantren. Pembelajaran santri yang dimaksudkan adalah bagaimana cara santri belajar dan memahami jadwal pembelajaran serta kesaharian.

Pendidikan pondok pesantren perlu disesuaikan dengan kebutuhan masyarakat atau sebagai alternative pemecahan masalah yang muncul di 
tengah-tengah masyarakat untuk itu penafsiran-penafsiran ajaran Islam yang bersumber dari berbagai kitab yang merupakan ciri khas tradisi pondok pesantren perlu di jabarkan secara detail untuk mempermudah pemahan santri dan dapat di praktikan sebagai pranata dalam kehidupan sosial serta dikembangkan dengan cara modern dan praktis untuk memotivasi dan menumbuhkan kesadaran baru dan mengamalkan ajaran agama.

Sebagai lembaga yang bergerak dalam bidang pendidikan Islam dan sosial keagamaan, pengembangan pesantren harus didorong. Karena pengembangan pesantren tidak terlepas dari adanya kendala yang harus dihadapinya. Apalagi belakangan ini, dunia secara dinamis telah menunjukkan perkembangan dan perubahan secara cepat, yang tentunya baik secara langsung maupun tidak langsung dapat berpengaruh terhadap dunia pesantren. Akan tetapi pengembangan pesantren tidak lantas di topang oleh lembaga, institusi atau budaya lain, sebab pesantren merupakan lembaga pendidikan Islam yang paling otonom yang tidak dapat di intervesi pihak manapun kecuali kiai.

Pendidikan pesantren sebagai pendidikan tertua di Indonesia, hingga saat ini masih bertahan ditengah-tengah image negative dan modernisasi pendidikan di luar pesantren itu sendiri. Pesantren sesungguhnya terbangun dari konstruksi kemasyarakatan yang menciptakan suatu transendensi atas perjalanan historis sosial. Pesantren sebagai lembaga pendidikan yang pada umumnya menyelenggarakan berbagai satuan pendidikan baik dalam bentuk sekolah maupun madrasah.

Pesantren bukan sekedar mengaji teori tetapi sekaligus praktek yang ada akhirnya melahirkan pembiasaan dan akan terwujud dalam kepribadian yang luhur (al akhlaq al karim). Menurut Abdurrahman wahid ada tiga elemen yang membentuk pondok pesantren: pertama pola kepemimpinan pondok pesantren yang mandiri tidak terkooptasi oleh Negara. Kepemimpinan kiai-ulama di pondok pesantren adalah sangat unik. Relasi sosial anatar kiai - ulama dan santri dibangun atas landasan kepercayaan, bukan karena patron klien sebagaimana dilakukan masyarakat pada umumnya. Ketaatan santri pada kiainya lebih kepada mengharapkan barokah (grace) sebagimana dipahami dalam konsep sufi.

Dilihat dari proses lahirnya, pondok pesantren merupakan institusi keagamaan yang tidak mungkin bisa dilepaskan dari masyarakat, 
khususnya masyarakat pedesaan. Lembaga pesantren tumbuh dan berkembang dari dan untuk masyarakat dengan memosisikan pesantren sebagai bagian masyarakat dalam pengertiannya yang transformativ. Dalam konteks ini pendidikan pesantren pada dasarnya merupakan pendidikan yang sarat dengan nuansa transformasi sosial. Pesantren telah mampu membuat masyarakat menyadari tentang arti kehidupan yang sebenarnya dan mengetahui persoalan konkret yang mereka hadapi sehingga mereka menjadi tidak gampang serta lebih berdaya dalam menyikapi kehidupan dengan segala kompleksitas persoalannya.

Pesantren berusaha meletakkan visi dan kiprahnya dalam kerangka pengabdian sosial yang pada mulanya ditekankan kepada pembentukan moral keagamaan. Pembentukan moral keagamaan inilah yang menjadi focus arah pembelajan dalam dunia pesantren (Abd a'ala, 2006: 2).

\section{B. PEMBAHASAN}

\section{Manajemen Pembelajaran Pesantren}

Pengertian manajemen pembelajaran berasal dari Bahasa Latin, yaitu dari asal kata manus yang berarti tangan, dan agere (melakukan). Katakata itu digabung menjadi managere yang artinya menangani. Managere diterjemahkan ke Bahasa Inggris to manage (kata kerja), management (kata benda), dan manager untuk orang yang melakukannya. Management diterjemahkan ke Bahasa Indonesia menjadi manajemen atau pengelolaan (Husaini, 2013: 5).

Menurut pendapat G. R Terry yang dikutip oleh Saefullah manajemen adalah proses khas yang terdiri atas tindakan-tindakan perencanaan, pengorganisasian, penggerakan, dan pengendalian yang dilakukan untuk menentukan serta mencapai sasaran yang telah ditentukan melalui sumber daya manusia dan sumber daya lainnya. Sedangkan menurut James A. F Stoner yang dikutip oleh Saefullah juga mendefinisikan manajemen sebagai proses perencanaan, pengorganisasian, dan penggunaan sumber daya organisasi lainnya agar mencapai tujuan organisasi lainnya agar mencapai tujuan organisasi yang telah ditetapkan (Saefullah, 2014: 3).

Manajemen merupakan serangkaian kegiatan merencanakan, mengorganisasikan, menggerakkan, mengendalikan, dan mengembangkan segala upaya dalam mengatur dan mendayagunakan sumber daya manusia, sarana dan prasarana secara efisien untuk mencapai tujuan organisasi yang telah ditetapkan (Sudjana, 2004: 17). 
Pembelajaran berasal dari kata belajar, menurut pandangan B.F Skinner belajar merupakan suatu proses adaptasi atau penyesuaian tingkah laku yang berlangsung secara progresif. Sedangkan menurut Gagne belajar merupakan kegiatan yang kompleks, belajar berupa kapasitas, dan timbulnya kapasitas disebabkan stimulasi yang berasal dari lingkungan dan proses kognitif yang dilakukan oleh pelajar. Belajar terdiri dari tiga komponen penting yakni kondisi eksternal yaitu stimulus dari lingkungan, internal yang menggambarkan keadaan internal (diri). Proses kognitif serta hasil belajar siswa yang menggambarkan informasi ferbal, keterampilan intelek, keterampilan motorik, sikap, dan siasat kognitif (Syaifurahman, 2013: 56).

Pembelajaran berasal dari kata "intruction" yang berarti "pengajaran" yang berarti proses membuat orang belajar. Menurut Gagne dan Brigge mendefinisikan pembelajaran sebagai suatu rangkaian even (kejadian, peristiwa, kondisi) yang sengaja dirancang untuk mempengaruhi peserta didik, sehingga proses belajaranya dapat berlangsung dengan mudah (Mulyono, 2012: 7). Pembelajaran pada hakikatnya adalah suatu proses interaksi antara pendidik dengan peserta didik, anak dengan sumber belajar, dan anak dengan pendidik. Sedangkan Menurut Kamus Besar bahasa indonesia pengajaran adalah proses perbuatan, cara mengajar atau mengajarkan. Dari pengertian diatas dapat dikatakan bahwa pembelajaran merupakan proses interaksi antara peserta didik dengan tenaga pendidikan serta sumber belajar dalam lingkungan belajar.

Menurut Ibrahim Bafadhal, manajemen pembelajaran adalah segala usaha pengaturan proses belajar mengajar dalam rangka tercapainya proses belajar mengajar yang efektif dan efisien. Manajemen program pembelajaran sering disebut dengan manajemen kurikulum dan pembelajaran (Bafadhal, 2004: 11). Pada dasarnya manajemen pembelajaran merupakan pengaturan semua kegiatan pembelajaran, baik dikategorikan berdasarkan kurikulum inti maupun penunjang berdasarkan kurikulum yang telah ditetapkan sebelumnya, oleh Departemen Agama atau Departemen Pendidikan Nasional. Dengan berpijak dari beberapa pernyataan di atas, kita dapat membedakan konsep manajemen pembelajaran dalam arti luas dan dalam arti Sedang manajemen pembelajaran dalam arti sempit diartikan sebagai kegiatan yang perlu dikelola oleh guru selama terjadinya proses interaksinya dengan siswa dalam pelaksanaan pembelajaran. 


\section{Fungsi manajemen pembelajaran}

Memang banyak macamnya dan selalu berkembang maju, baik dalam bentuk penambahan maupun pengurangan sesuai dengan perkembangan teori organisasi dari waktu ke waktu dan disesuaikan dengan kebutuhan organisasi pada waktu bersangkutan.Untuk mencapai tujuannya, organisasi memerlukan dukungan manajemen dengan berbagai fungsinya yang disesuaikan dengan kebutuhan organisasi masing-masing.

Dalam mengelola pembelajaran guru melakukan langkah kegiatan pembelajaran yaitu: Perencanaan pembelajaran Perencanaan adalah menyusun langkah-langkah yang akan dilaksanakan untuk mencapai tujuan yang telah ditentukan. Perencanaan tersebut dapat disusun berdasarkan kebutuhan dalam jangka waktu tertentu sesuai dengan keinginan pembuat perencanaan. Perencanaan pembelajaran dapat diartikan sebagai proses penyusunan materi pelajaran, penggunaan media pembelajaran, penggunaan pendekatan atau metode pembelajaran, dan penilaian dalam suatu alokasi waktu yang akan dilaksanakan pada masa tertentu untuk mencapai tujuan yang ditentukan.

Fungsi perencanaan dalam kegiatan pembelajaran diindikasikan dengan aplikasi prinsip-prinsip perencanaan pembelajaran yaitu: pertama, menetapkan apa yang hendak dilakukan oleh guru, kapan dan bagaimana melakukannya dalam implementasi pembelajaran. Kedua, membatasi sasaran atas dasar tujuan instruksional khusus dan menetapkan pelaksanaan kerja untuk mencapai hasil yang maksimal. Ketiga, melalui proses penentuan target pembelajaran. Keempat, mengembangkan alternatif-alternatif yang sesuai dengan strategi pembelajaran. Kelima, Mengumpulkan dan menganalisis informasi yang penting untuk mendukung kegiatan pembelajaran. Keenam, mempersiapkan dan mengkomunikasikan rencana-rencana dan keputusan-keputusan yang berkaitan dengan pembelajaran kepada pihak-pihak yang berkepentingan.

Pengorganisasian pembelajaran Fungsi pengorganisasian meliputi penentuan fungsi, hubungan dan struktur. Fungsi berupa tugas-tugas yang dibagi ke dalam fungsi garis staf, dan fungsional. Hubungan terdiri atas tanggung jawab dan wewenang. Sedangkan strukturnya dapat horisontal atau vertikal. Semuanya itu memperlancar alokasi sumber 
daya dengan kombinasi yang tepat untuk mengimplementasikan rencana (Nanang, 2001: 2). Yang tidak kalah penting dalam pengorganisasian adalah pembagian tugas, wewenang dan tanggung jawab haruslah dikondisikan dengan bakat, minat, pengalaman, dan kepribadian masing-masing personil yang dibutuhkan dalam melaksanakan tugastugas organisasi tersebut.

Pelaksanaan pembelajaran Pelaksanaan proses pembelajaran merupakan pelaksanaan strategi-strategi yang telah dirancang untuk mencapai tujuan pembelajaran. Pelaksanaan pembelajaran merupakan interaksi guru dan peserta didik dalam rangka penyampaian bahan ataupun materi pelajaran kepada siswa untuk mencapai tujuan (Saekhan, 2008: 110).

Pelaksanaan pembelajaran adalah melaksanakan apa yang telah dipersiapkan seperti tujuan yang telah ditentukan, materi, metode serta strategi yang relevan. pelaksanaan strateg-strategi yang telah dirancang untuk mencapai tujuan pembelajaran. Mengenai penerapan fungsi pengorganisasian dalam kegiatan pembelajaran, ditunjukkan dengan sejumlah indikator, diantaranya: pertama, Menyediakan fasilitas, perlengkapan, dan personil yang diperlukan untuk menyusun kerangka yang efisien dalam melaksanakan rencana-rencana melalui suatu proses penetapan pelaksanaan pembelajaran yang diperlukan untuk menyelesaikannya. Kedua, Membentuk struktur wewenang dan mekanisme koordinasi pembelajaran, merumuskan dan menetapkan metode dan prosedur pembelajaran. Ketiga, Memilih, mengadakan latihan, dan pendidikan dalam upaya pengembangan jabatan guru yang dilengkapi dengan sumber-sumber lain yang diperlukan. Keempat, Pengawasan pembelajaran

Fungsi pengawasan meliputi penentuan standar, supervisi, dan mengukur penampilan/ pelaksanaan terhadap standar dan memberikan keyakinan bahwa tujuan organisasi tercapai. Pengawasan sangat erat kaitannya dengan perencanaan, karena melalui pengawasan efektivitas manajemen dapat diukur (Wibowo, 2006: 13). Dengan demikian pengawasan merupakan suatu kegiatan yang berusaha untuk mengendalikan agar pelaksanaan dapat berjalan sesuai dengan rencana dan memastikan apakah tujuan organisasi tercapai. Apabila terjadi penyimpangan dimana letak penyimpangan itu dan bagaimana pula tindakan yang diperlukan untuk mengatasinya. 
Evalauasi pembelajaran Istilah evaluasi berasal dari bahasa inggris yaitu "evaluation". Menurut Wand dan Gerald W. Brown evaluasi adalah suatu tindakan atau suatu proses untuk menentukan nilai dari sesuatu (Oemar, 2008: 156). Evaluasi sebagai alat penilai hasil pencapaian tujuan dalam pengajaran yang harus dilakukan secara terus menerus. Evaluasi bukan hanya sebagai penentu angka keberhasilan belajar namun juga sebagai feedback atau umpan balik dari pembelajaran. Fungsi pengawasan dalam kegiatan pembelajaran, diimplikasikan dengan sejumlah indikator, yaitu: Mengevaluasi pelaksanaan kegiatan dibanding dengan rencana pembelajaran. Melaporkan penyimpangan untuk tindakan koreksi dan merumuskan tindakan koreksi, menyusun standar-standar pembelajaran dan sasaran-sasaran. Menilai pekerjaan dan melakukan tindakan koreksi terhadap penyimpanganpenyimpangan, baik institusional satuan pendidikan maupun proses pembelajaran.

Sedangkan jika kita merujuk pada pesantren atau familiar disingkat ponpes merupakan sebuah asrama pendidikan tradisional yang mana para siswanya disebut santri semua tinggal bersama dan belajar di bawah bimbingan guru yang lebih dikenal dengan sebutan kiai dan mempunyai asrama untuk tempat menginap santri. Santri tersebut berada dalam kompleks yang juga menyediakan masjid untuk beribadah, ruang belajar, dan kegiatan keagamaan lainnya. Kompleks biasanya dikelilingi oleh tembok untuk dapat mengawasi keluar masuknya para santri sesuai denga peraturan yang berlaku (Zamakhsyari, 1993: 18).

Jika dikaji lebih dalam berdasarkan asal katanya pondok pesantren merupakan dua istilah yang menunjukkan satu pengertian. Pesantren menurut pengertian dasarnya adalah tempat belajar santri. Sedangkan pondok berarti rumah atau tempat tinggal sederhana terbuat dari bambu. Disamping itu, kata pondok berasal dari bahasa Arab funduq yang berarti asrama atau hotel, di jawa termasuk sunda dan Madura umumnya digunkan istilah pondok dan pesantren, sedangkan di aceh dikenal dengan istilah dayah atau rangkang atau menuasa, sedangkan di minangkabau di sebut surau (Nurcholis, 1997: 5).

Pesantren menurut Kamus Besar Bahasa Indonesia berarti "asrama tempat santri atau tempat murid-murid belajar mengaji....." Akar kata pesantren berasal dari kata "santri", yaitu istilah yang pada awalnya digunakan bagi orang-orang yang menuntut ilmu agama dilembaga pendidikan tradisional Islam. Menurut Johns bahwa pesantren berasal 
dari bahasa Tamil yang berarti guru mengaji, sedangkan menurut C. C Berg pesantren berasal dari bahasa India shastra yang berarti bukubuku suci, buku-buku agama, dan buku-buku pengetahuan (Fatah, 2005: $10)$.

\section{Manajemen Pembelajaran Pondok Pesantren Al-Falah}

Dari perspektif kependidikan, pesantren merupakan satu-satunya lembaga kependidikan yang tahan terhadap berbagai gelombang modernisasi. Dengan kondisi demikian itu, kata Aziyumardi Azra, menyebabkan pesantren tetap survive sampai hari ini. Sejak dilancarkannya perubahan atau modernisasi pendidikan Islam diberbagai Dunia Islam, tidak banyak lembaga-lembaga pendidikan tradisional Islam seperti pesantren yang mampu bertahan. Kebanyakan lenyap setelah tergusur oleh ekspansi sistem pendidikan umum atau sekuler. Nilai-nilai progresif dan inovatif diadopsi sebagai suatu strategi untuk mengejar ketertinggalan dari model pendidikan lain. Dengan demikian, pesantren mampu bersaing dan sekaligus bersanding dengan sistem pendidikan modern (Nizar, 2011: 186). Budaya pesantren yang menekankan kesetaraan, kerakyatan dan keadilan telah melahirkan suatu perubahan masyarakat yang modern,namun tetap berpijak pada landasan tradisionalitas dan moralitas. Pesantren telah menemukan kemajemukan dan kedinamisan sebagai sebuah lembaga multi personal yang melibatkan partisipasi dan peran kiai, santri, ustadz, masyarakat, dan pemerintah (Tim Pekapontren, 2004: 84).

Nurcholish madjid mengajukan dua pendapat yang dapat dipakai sebagai acuan untuk melihat asal-usul perkataan santri. Pendapat pertama mengatakan bahwa santri berasal dari kata sastri dari bahasa sanskerta yang artinya melek huruf. Pendapat kedua mengatakan bahwa kata santri berasal dari bahasa jawa cantrik, artinya seorang yang mengabdi kepada seorang guru. Misalnya seseorang yang ingin menguasai keahlian atau kepandaian dalam pewayangan menjadi dalang atau menabuh gamelan, ia akan mengikuti seorang yang sudah ahli dibidang pewayangan tersebut. Pola hubungan guru cantrik kemudian diteruskan. Pada proses evolusi selanjutnya, istilah guru cantrik berubah menjadi guru santri karena guru dipakai secara luas, untuk guru yang terkemuka kemudian digunakan kata kyai, yang mengandung arti tua atau sakral, keramat, dan sakti. Pada perkembangan selanjutnya, dikenal istilah kyai-santri. Karakteristik atau ciri-ciri umum pondok pesantren 
adalah adanya kiai, santri, masjid, dan pondok atau asrama. Sedangkan ciri-ciri khusus pondik pesantren adalah isi kurikulum yang dibuat terfokus pada ilmu-ilmu agama, misalnya ilmu sintaksis arab, morfologi arab, hukum islam, tafsir hadits, tafsir al-qur'an dan lain-lain.

Ciri-ciri diatas menggambarkan pendidikan pesantren dalam bentuknya yang masih murni (tradisional). Adapun penampilan pendidikan pesantren sekarang yang lebih beragam merupakan akibat dinamika dan kemajuan zaman telah mendorong terjadinya perubahan terus-menerus sehingga lembaga tersebut melakukan berbagai adopsi dan adaptasi sedemikian rupa (Sudadi, 2016: 165). Pesantren tidak hanya berfungsi sebagai lembaga pendidikan, tetapi juga berfungsi sebagai lembaga sosial dan penyiaran keagamaan. Sebagai lembaga pendidikan pesantren menyelenggarakan pendidikan formal (madrasah, sekolah umum, perguruan tinggi) dan non formal. Sebagai lembaga sosial, pesantren menampung anak-anak dari segala lapisan masyarakat muslim tanpa membeda-bedakan status sosial, menerima tamu yang datang dari masyarakat umum dengan motif yang berbeda-beda.

\section{Profil Pesantren Al-Falah Somalangu}

Sejarah Berdirinya Pondok Pesantren Al-Falah Somalangu Desa Sumberadi Kecamatan Kebumen. Pondok Pesantren Al-Falah Somalangu Sumberadi Kebumen ialah Pondok Pesantren yang terletak di desa Sumberadi 02/02 desa Sumberadi Kecamatan Kebumen Kabupaten Kebumen. Pengasuh Pondok Pesantren Al-Falah Somalangu adalah KH. Agus Musyafa 'Aly yang terkenal dengan sebutan Gus Musafa. Gus Musafa bukanlah orang asli Somalangu melainkan berasal dari Kecamatan Parakan Kabupaten Temanggung. Gus Musafa dijadikan menantu oleh KH. Toifur bin 'Abdurrohman pada saat menuntut ilmu di pondoknya. Sebelumnya Gus Musafa juga pernah menimba ilmu di beberapa Pondok Pesantren seperti : PP Al-Falah Ploso Mojo Kediri, PP API Tegal Rejo Magelang,dan Pondok Pesantren Parakan Temanggung. Awal mulanya Pondok Pesantren Al-Falah didirikan tahun 1992. Beliau membangun Pondok Pesantren Al-Falah di tanah milik sendiri, dalam proses pembangunan Pondok Pesantren dibantu santri dan warga setempat yang turut gotong royong. Pembangunan ini selesai diresmikan pada tahun 1993. Susunan Organisasi Pengurus Pondok Pesantren Al-Falah somalangu desa sumberadi kecamatan kebumen Pengasuh: KH. Agus Musyafa 'Aly. H. Agus Faiq Muflihin Al-Hunaivi. H. 
Muhammad Zulvian Ikfina. Penasehat: K. Bahran, Ketua Umum: Ali Mutaqin, Wakil: Muklis Warodi, Bendahara: A.Mustaqim Zain. Keamanan: Miftahudin, Sekretaris: M. Kharis Faturohman.

\section{Metode Pembelajaran di Pesantren Al Falah Somolangu}

Sistem pembelajaran di pondok Al-Falah memiliki berbagai proses antara lain dalam segi pengajaran, metode pembelajaran sampai evaluasi atau akhir dari proses pendidikan. Berikut metode pembelajaran yang ada di Pondok Pesantren Al-Falah:

Bandungan Metode bandungan merupakan metode dimana seorang kyai membacakan kitab, memaknai (mengartikan dalam Bahasa jawa pegon) dan menerangkan tentang isi kitab yang dikaji dihadapan para santri. Sedangkan para santri duduk berkumpul dihadapan kyai dengan membawa kitab yang sama judulnya dengan kitab yang dibacakan oleh kyai. Namun kitab yang dibawa oleh para santri ini adalah kitab yang belum ada harokat maupun makna (arti)-nya. Mereka menyimak kitab mereka masing-masing dengan sesekali memberikan makna/arti pada kitab mereka dalam bentuk makna jawa pegon (tulisan huruf hijaiyah yang dibaca dalam Bahasa jawa).

Sorogan Berbeda dengan metode bandungan yang sifatnya kelompok, pengajian sorogan justru merupakan metode yang sifatnya individual. Dalam metode ini, santri secara individual menghadap kepada kyai atau ustadz untuk menyampaikan hasil belajar atau hafalannya mengenai suatu kitab. Kemudian kyai atau ustadz menyimak dan mengoreksi kesalahan dan membenarkannya.

Syawir merupakan metode dimana santri secara bebas bertanya mengenai tema yang dibahas, kemudian santri-santri yang lain memberikan pendapat atau jawaban atas pertanyaan atau masalah tersebut.

Lalar Metode ini merupakan salah satu pengembangan metode yang sudah ada di pesantren Al-Falah. Dalam metode ini, mula-mula ustadz atau ustadzah membacakan sebuah kitab, kemudian dipelajari secara individu ataupun kelompok oleh para santri. Selanjutnya pada hari berikutnya, beberapa santri yang ditunjuk secara acak maju ke depan kelas untuk menyampaikan hasil belajarnya mengenai materi yang dibacakan oleh ustadz atau ustadzah pada hari sebelumnya. Metode ini agak mirip dengan metode presentasi dalam kuliah. 
Mutholangah Mutholangah merupakan metode pengulangan materi oleh ustadz yang akan mengajar. Dalam metode ini, ustadz atau santri mengaji ulang kitab yang sudah pernah dikajinya dari kyai atau ustadz yang lain untuk memantapkan pemahaman mereka terhadap suatu kitab. Mereka juga terkadang meminta penjelasan kepada teman sesama ustadz mengenai isi kitab yang dikajinya tersebut yang sekiranya masih menimbulkan pertanyaan atau belum dikuasainya secara penuh.

Tamrin Metode tamrin merupakan salah satu bentuk penilaian atau evaluasi yang dilakukan oleh pada ustadz maupun ustadzah kepada para santri. Metode ini dilakukan secara berkala, biasanya setelah menyelesaikan satu atau beberapa bab. Penilaian ini dilakuakan pada pengajian dengan sistem Madrasah Diniyah, dan jarang dilakukan dalam pengajian umum bersama kyai.

Tikror Metode tikror ini diadakan sesaat sebelum pengajian madrasah diniyah dimana santri berkelompok masing-masing dua orang. Selanjutnya, mereka secara bergantian melakukan tanya jawab mengenai materi yang sudah diajarkan oleh kyai atau ustadz. Metode ini efektif untuk mengingat kembali materi-materi pelajaran yang sudah didapat melalui pengajian-pengajian sebelumnya. Kegiatan ini dilihat dalam suatu observasi. Kegiatan ini saya lihat sangat membantu untuk mempermudah dalam memahami ilmu yang di kaji.

Hafalan dan Setoran Metode ini merupakan salah satu metode klasik yang masih tetap dipertahankan di pesantren, termasuk di Pondok Pesantren Al-Falah. Dalam metode ini, santri baik secara individu maupun kolektif menghafalkan suatu kitab (biasanya berbentuk baitbait yang berisi mengenai suatu kaidah tertentu, baik aqidah, maupun nahwu shorof). Selanjunya mereka satu per satu maju ke depan menyetorkan hasil hafalam mereka di hadapan kyai atau ustadz.

Qiroati Metode qiro'ati merupakan salah satu metode yang sudah terkenal di masyarakat luas sebagai metode yeng digunakan untuk belajar membaca Al-Qur'an. Dalam metode ini, Kyai atau ustadz pertama-tama melafadkan suatu bacaan huruf hijaiyah yang baik dan benar sesuai dengan kaidah tajwid dan makhrojnya. Selanjutnya, santri secara individual maupun kolektif menirukan bacaan kyai atau ustadz tersebut dan diulang beberapa kali sampai bacaan mereka benar semua.

Selain kegiatan pengajian sebagaimana dalam pembahasan di atas, juga terdapat kegiatan tambahan. Kegiatan tambahan ini bertujuan untuk memberikan pengetahuan dan keterampilan lebih kepada para 
santri. Karena bersifat tambahan, maka jadwalnya pun menyesuaikan, yaitu selain jadwal kegiatan pengajian di atas. Kegiatan tambahan tersebut antara lain: tarbiyatul khitobah, tadarus 30 juz, hadroh dan barzanji, muthola'ah, mukhafadhoh, pelatihan hadroh, mujahadah, sholat dhuha dan dalailan.

\section{KESIMPULAN}

Berdasarkan pembahasan yang sudah dipaparkan, maka dapat diambil kesimpulan bahwa sistem pembelajaran santri yang digunakan oleh Pondok Pesantren Al-Falah Somalangu adalah penerapan metode salafiyah/tradisisonal. Dengan sembilan metode pembelajaran yakni bandungan, sorogan, syawir, lalar, mutholangah, tamrin, tikror, hafalan dan setoran, dan qiroati. Sedangkan manajemen pembelajaran yang dilakukan itu mencangkup fungsi manajemen yang terdiri atas perencanaan pembelajaran, pengorganisasian pembelajaran, pelaksanaan pembelajaran, pengawasan pembelajaran dan evaluasi pembelajaran. 


\section{DAFTAR PUSTAKA}

Abd a’ala. 2006. Pembaharuan Pesantren. Yogyakarta: Pustaka Pesantren.

Ali, A. 2011. Pembaharuan Pendidikan di Pesantren. Yogyakarta: Pustaka Pelajar.

Bafadhal. 2004. Perencanaan Pengajaran Berdasarkan Pendekatan Sistim. Jakarta : PT Bumi Aksara.

Dhofier, Z. 1993. Tradisi Pesantren Studi Tentang Pandangan Hidup Kyai. Jakarta: LP3S.

Fatah, H \& Rohadi, A. 2005. Rekontruksi Pesantren Masa Depan. Jakarta : Lista Fariska Putra.

Fattah, N. 2001. Landasan Manajemen Pendidikan. Bandung: Remaja Rosdakarya.

Hamalik, O. 2008. Kurikulum dan Pembelajaran. Jakarta: PT.Bumi Aksara.

Majid, N. 1997. Bilik-Bilik Pesantren Sebuat Potren Perjalanan. Jakarta: Paramadina..

Muchit, S. 2008. Pembelajaran Kontekstual. Semarang : Rasail Media Grup.

Mulyono. 2012. Strategi Pembelajaran: Menuju Efektifitas Pembelajaran di Abad Global. Malang: UIN-Maliki-Press.

S, Sudjana. 2004. Manajemen Program Pendidikan. Bandung: Falah Production.

Saefullah. 2014. Manajemen Pendidikan Islam. Bandung: CV Pustaka Setia.

Sudadi. 2016. Sejarah Pendidikan Islam di Indonesia. Yogyakarta: Pustaka Ilmu.

Syaifurahman dan Tri Ujiati. 2013. Manajemen Dalam Pembelajaran. Jakarta: Indeks.

Tim Pekapontren. Potensi Ekonomi Pondok Pesantren di Indonesia. Jakarta: Direktorat Pekapontren.

Usman, H. 2013. Manajemen Teori, Praktik, dan Riset Pendidikan. Jakarta: PT Bumi Aksara.

Wibowo. 2006. Manajemen Perubahan.Jakarta: RajaGrafinso Persada. 